\title{
Wartości organizacyjne wybranych firm w Polsce
}

\author{
Corporate Values of Selected Poland-Based Companies
}

\author{
Ewa Jastrzębska \\ Kolegium Ekonomiczno-Społeczne, Szkoła Główna Handlowa w Warszawie \\ ORCID: https://www.orcid.org/0000-0002-0029-6943• ewa.jastrzebska@sgh.waw.pl \\ Zgłoszono: 5.03.2020; zrecenzowano: 15.05.2020; zaakceptowano do druku: 20.05.2020
}

\begin{abstract}
Streszczenie: Współczesne wyzwania (kryzys klimatyczny, utrata bioróżnorodności, życie w świecie VUCA), w tym kryzys przywództwa i narastające zagrożenia globalne sprawiają, że powraca pytanie o wartości fundamentalne, także w biznesie przyczyniającym się do wielu obecnych problemów. W dzisiejszych czasach wartość w biznesie przestaje być już rozumiana wyłącznie w kategoriach ekonomicznych, a zarządzanie przez wartości staje się fundamentem efektywnej firmy. Celem opracowania jest ocena wartości organizacyjnych liderów społecznej odpowiedzialności biznesu (CSR) w Polsce dokonana na tle próby zdefiniowania zarządzania przez wartości i samych wartości organizacyjnych. Zarządzanie przez wartości można uznać za filozofię, jak i rzeczywisty, praktyczny proces wyjaśniania wartości organizacji, skutecznego ich komunikowania i dostosowywania do nich praktyk biznesowych. Przeprowadzone wśród liderów CSR badanie pozwoliło zauważyć zmianę wartości - kluczowa dla firm stała się odpowiedzialność (którą firmy potrafią intepretować bardzo szeroko, odnosząc ją do różnych grup interesariuszy) i inne wartości behawioralne. Widać także wzrost popularności wartości uczciwość. Zaskakujący jest natomiast spadek znaczenia wartości społecznościowych (nastawionych na otoczenie i środowisko) w kontekście obecnych zagrożeń globalnych, z których środowiskowe zaczyna się zaliczać do kluczowych.
\end{abstract}

Słowa kluczowe: zarządzanie poprzez wartości, wartości organizacyjne, przedsiębiorstwo, CSR

\begin{abstract}
Contemporary challenges (climate crisis, bio-diversity loss, living in a VUCA world), including a leadership crisis and emerging global threats, raise the question of fundamental values, also in business, which is often regarded as the source of many present-day problems. Nowadays in business, the idea of value does no longer refer solely to financial results and value-based management becomes the key driver of burgeoning companies. This study, therefore, aims to assess the organizational values of corporate social responsibility (CSR) leaders in Poland, while also attempting to define value-based management and corporate values as such. Managing by values can be considered to be both a philosophy and a realistic, practical process for clarifying an organisation's beliefs, communicating them effectively, and aligning business practices with them. In a recent survey conducted with CSR leaders, a shift in values was revealed: responsibility (which companies can interpret very widely, when referring it to different groups of stakeholders), and other behavioural values, are now at the heart of business in many companies. There is also an increase in the application of honesty, whilst a decline in societal values (focused on the environment and the nature) was surprising, in the context of the current global threats with the environmental ones at the fore.
\end{abstract}

Keywords: managing by values, value-based management, corporate values, enterprise, CSR 


\section{Wprowadzenie}

W mowie noblowskiej Olga Tokarczuk stwierdziła: „Świat umiera, a my nawet tego nie zauważamy. Nie zauważamy, że świat staje się zbiorem rzeczy i wydarzeń, martwą przestrzenią, w której poruszamy się samotni i zagubieni, miotani czyimiś decyzjami, zniewoleni niezrozumiałym fatum, poczuciem bycia igraszką wielkich sił historii czy przypadku. [...] Marzy mi się także nowy rodzaj narratora - «czwartoosobowego», który [...] potrafi zawrzeć w sobie zarówno perspektywę każdej z postaci, jak i umiejętność wykraczania poza horyzont każdej z nich, który widzi więcej i szerzej [...].Widzieć wszystko oznacza też zupełnie inny rodzaj odpowiedzialności za świat, ponieważ staje się oczywiste, że każdy gest «tu» jest powiązany z gestem «tam», że decyzja podjęta w jednej części świata poskutkuje efektem w innej jego części, że rozróżnienie na «moje» $\mathrm{i}$ «twoje» zaczyna być dyskusyjne" (Tokarczuk 2019).

Współczesny kryzys wartości i przywództwa sprawia, że ludzie czują się zagubieni, brakuje im systemu wartości, którym kierowaliby się w życiu, oraz autorytetów, które byłyby dla nich wzorem. Doświadczenia $\mathrm{XX}$ w. pokazały, że nie ma podstawowych, powszechnych, absolutnych i niezmiennych wartości etycznych, jak to było w poprzednich stuleciach. Zdaniem Wiesława Sztumskiego, współcześnie mamy do czynienia $z$ etykami fundowanymi na wartościach zmiennych i dostosowywanych do wymogów aktualnie panujących ideologii, wyznań religijnych oraz polityki, a także na użytek różnych grup społecznych, w szczególności korporacji (Herman 2015, 29-30). W raporcie Światowego Forum Ekonomicznego z 2015 r. 86\% z prawie 1800 ekspertów uznało, że jednym z globalnych problemów jest brak przywództwa (Petriglieri 2020). Kryzys wartości i przywództwa jest jeszcze dobitniej zauważalny przez narastające problemy globalne zagrażające ludzkości, jak np. zmiany klimatyczne czy utrata bioróżnorodności oraz fakt, że żyjemy w świecie VUCA, czyli zmiennym (volatility), niepewnym (uncertainty), złożonym (complexity) i niejednoznacznym (ambiguity). Wyzwania te sprawiają, że powraca pytanie o wartości fundamentalne, także w biznesie przyczyniającym się do wielu współczesnych zagrożeń.

W dzisiejszych czasach świadomi inwestorzy, konsumenci i pracownicy (zwłaszcza najmłodsze pokolenia Y i Z) $)^{1}$, coraz częściej zwracają uwagę na to, co zaczyna się uważać za fundament efektywnej firmy, czyli jej wartości, które przestały być tylko filozoficznym celem, czy instrumentalnie traktowanym rekwizytem, lecz stały się swoistym DNA, które pozwala zachować ciągłość organizacji i utrwalić jej sukces rynkowy (FIG Polska 2020). Zarządzanie przez wartości (ZPW) czy koncepcja społecznej odpowiedzialności (biznesu - CSR) ${ }^{2}$ są koncepcjami zbudowanymi na etyce, która staje się kryterium nie tylko realizowania celów, lecz także ich określania. Wartość w biznesie przestaje być już rozumiana wyłącznie w kategoriach ekonomicznych, tak jak głównym celem przedsiębiorstwa przestaje być maksymalizacja zysku czy wartości tylko właścicielskiej.

Celem opracowania jest ocena wartości organizacyjnych liderów społecznej odpowiedzialności biznesu w Polsce dokonana na tle próby zdefiniowania zarządzania przez wartości i samych wartości organizacyjnych. Postawiono następujące pytania badawcze, przekładające się na strukturę opracowania:

- Na czym polega zarządzanie przez wartości?

- Czy wartości osobiste różnią się od wartości organizacyjnych?

- Jakie wartości deklarują wybrane przedsiębiorstwa w Polsce, w tym liderzy społecznej odpowiedzialności biznesu?

1 Generacja X to osoby urodzone między 1961 a 1985 r., czyli dzieci baby boomersów, pokolenia powojennego wyżu demograficznego. Generacja Y, czyli milenialsi, to osoby urodzone w latach 1986-1997, a pokolenie Z - osoby urodzone po $1997 \mathrm{r}$.

2 Chociaż obecnie mówi się o społecznej odpowiedzialności każdej organizacji, to skrót CSR (corporate social responsibility) przyjął się w Polsce i jest powszechnie używany. 
Opracowanie powstało na bazie krytycznej analizy literatury przedmiotu oraz web research, przede wszystkim stron internetowych analizowanych w badaniu firm.

\section{Zarządzanie poprzez wartości w organizacji}

W 1980 r. Robert H. Waterman Jr., Thomas J. Peters i Julien R. Phillips opracowali dla McKinseya model 7 S, ujmujący niematerialne elementy organizacji: twarde (strategia; struktura organizacyjna; procedury - formalne i nieformalne) oraz miękkie (style - zarządzania i zachowania; pracowników; umiejętności i kompetencje; nadrzędne cele) $)^{3}$. W tym modelu nadrzędne cele były rozumiane jako zestaw wartości i aspiracji, a zostały umieszczone centralnie wobec pozostałych elementów modelu dla podkreślenia, że stanowią fundamentalne idee, wokół których zbudowany jest biznes, punkt wyjścia dla wszelkich działań, spoiwo wszystkich elementów (Waterman i in. 1980, 17-25).

Koncepcję zarządzania przez wartości (managing by values) opracował Michael O'Connor na podstawie ponad 30 lat badań i współpracy z organizacjami i przedstawił w książce pod takim samym tytułem, napisanej wspólnie z Kenem Blanchardem (Blanchard and O'Connor 1998). Ich zdaniem ZPW to zarówno filozofia, jak i rzeczywisty, praktyczny proces wyjaśniania wartości organizacji, skutecznego ich komunikowania i dostosowywania praktyk biznesowych do nich, aby osiągnać nowy poziom wyników działalności (performance) (Lifeassociatesinc.com 2020). Podstawą tego procesu są jasne i trwałe wartości, które stosować należy zarówno podczas podejmowania strategicznych decyzji, jak i w codziennym funkcjonowaniu firmy. Według Blancharda i O’Connora zarządzanie przez wartości spaja cztery filary (CEOS), na których oparta jest firma, a które symbolizują grupy, wobec których jest ona odpowiedzialna: klientów

3 Nazwa pochodzi od pierwszych liter 7 składowych elementów modelu. (customers - C), pracowników (employees E), właścicieli (owners - O) i innych ważnych interesariuszy (significant others - S) (Blanchard and O'Connor 1998, 23-25).

Podobnie ZPW definiują Simon L. Dolan, Salvador Garcia i Bonnie A. Richley, określając zarządzanie przez wartości zarówno jako filozofię, jak i praktykę zarządzania, skoncentrowane na jednoczesnym utrzymaniu kluczowych wartości organizacji i powiązaniu ich z celami strategicznymi (Mierzwińska 2013, 342). Rozwinięciem tego ujęcia wydaje się być podejście Ilony Świątek-Barylskiej, która ZPW definiuje jako systematyczny proces wdrażania wartości organizacji do codziennych działań oraz kreowanie kultury organizacyjnej, która pozwoli przedsiębiorstwu świadczyć usługi wysokiej jakości i zapewnić wysoki standard życia pracowników (Mierzwińska 2013, 341342). Agata Stachowicz-Stanusch, autorka pierwszej w Polsce publikacji poświęconej ZPW, definiuje tę koncepcję jako „proces przekazywania głównych wartości organizacji z pokolenia zarządzających ${ }^{4}$ na kolejne ich pokolenie poprzez przejmowanie obowiązków wynikających z głównych wartości oraz ochrony ich w imieniu oraz dla korzyści organizacji i jej uczestników poprzez ich instytucjonalizację" (Stachowicz-Stanusch 2007, 38).

Prawie wszystkie przytoczone definicje wskazują, że ZPW jest procesem, choć wskazuje się różne jego etapy. Kilka propozycji przedstawiono w tabeli 1 .

Zarządzanie poprzez wartości odbiega od tradycyjnego sposobu zarządzania, ponieważ rozszerza pojęcie wartości, która staje się kategorią aksjologiczną a nie tylko ekonomiczną. Ze swojej istoty ZPW jest koncepcją wielowymiarową i nadal dys kusyjną - postrzega się ją albo jako nową koncepcję zarządzania, albo tylko nowe narzędzie, także marketingowe (Krajewska-Nieckarz 2013, 218). Wzrost znaczenia

4 Wydaje się, że przekazywanie obowiązków powinno dotyczyć nie tylko zarządzających, lecz także pracowników, którzy wartości konkretyzują w codziennych działaniach. 
Tabela 1. Etapy zarządzania poprzez wartości według wybranych autorów

\begin{tabular}{lll}
\hline K. Blanchard, M. O'Connor & A. Stachowicz-Stanusch & Firma edukacyjno-doradcza CSRinfo \\
\hline - sprecyzowanie swojej misji, celów & $\cdot$ odkrywanie głównych wartości & $\cdot$ wyłanianie wartości \\
i wartości & $\cdot$ rozwój głównych wartości & $\cdot$ definiowanie wartości \\
- propagowanie misji i wartości & $\cdot$ instytucjonalizacja głównych wartości & $\cdot$ wdrażanie wartości \\
- dostosowanie codziennych działań do & $\cdot$ redefiniowanie głównych wartości & $\cdot$ monitoring i kontrola \\
misji i wartości & & \\
\hline
\end{tabular}

Źródło: opracowanie własne na podstawie: (Blanchard and O’Connor 1998, 35; Stachowicz-Stanusch 2007, 38; Jastrzębska 2014, 81)

wartości w zarządzaniu wiąże się także z rozwojem koncepcji społecznej odpowiedzialności (biznesu), w którą wpisane jest uwzględnianie wartości innych niż tylko ekonomiczne. Międzynarodowa norma społecznej odpowiedzialności ISO 26000 definiuje bowiem tę koncepcję jako „odpowiedzialność organizacji za wpływ jej decyzji i działań na społeczeństwo i środowisko, poprzez przejrzyste i etyczne zachowanie, które [...] uwzględnia oczekiwania interesariuszy [...]" (Norma 2012, 14).

Będące pierwotnie przedmiotem nauk filozoficznych, współcześnie systemy wartości stały się także domeną nauk o zarządzaniu (rozważań związanych z kulturą organizacyjną czy tożsamością organizacyjną), co wynika $\mathrm{z}$ ich istoty, jaką jest wspieranie procesu decyzyjnego. Obecnie coraz więcej mówi się o formalnym wejściu aksjologii (nauki o wartościach) do innych dziedzin naukowych, jak np. ekonomii (mimo odmienności nauk ścisłych i społecznych). Zwłaszcza, że zgodnie z ekonomią behawioralną, człowiek jako podmiot gospodarujący nie jest racjonalnym homo oeconomicus, tylko ulega wpływowi różnych czynników uchodzących w teorii ekonomii klasycznej za rzekomo nieistotne (Thaler 2018), w tym systemom etycznym swoim i otoczenia. Jerzy Hausner (2019, 72-77) w tym kontekście używa pojęcia ekonomia wartości, zwracając uwagę, że nie da się sformułować poprawnej ekonomicznej teorii wartości bez uznania, że wartości mają społeczną, nie indywidualistyczną, naturę i to wartości egzystencjalne nadają sens naszemu istnieniu.

\section{Wartości osobiste a wartości organizacyjne}

Władysław Tatarkiewicz stwierdził, że zdefiniowanie wartości jest trudne, jeśli w ogóle możliwe (bo wartość to cecha prosta, niedająca się rozczłonkować, a cech prostych się nie definiuje) (Wiśniewski 1989, 293), a Jerzy Hausner dodał, że spór o naturę wartości jest wielki i wieczny (Hausner 2019, 18-19, 24). To może tłumaczyć mnogość definicji wartości, jaką można odnaleźć w literaturze. Aksjologia, jako odrębna dziedzina filozofii, narodziła się i rozwijała na przełomie XIX i XX w., jednak refleksją nad wartościami zajmowali się już filozofowie greccy (np. Pitagoras w swojej zasadzie homo mensura, zgodnie z którą człowiek staje się tym, który decyduje o wartościach, czy Platon w twierdzeniu o istnieniu królestwa absolutnych, wiecznych i niezmiennych idei z najwyższą ideą dobra). Mnogość teorii wartości można uporządkować, dokonując ich klasyfikacji ze względu na to, jaki sposób istnienia wartości uznają. Wartości mogą istnieć w (Koza-Granosz 2011):

- podmiocie (definicje relatywistyczne, subiektywistyczne, sprowadzające wartości do procesu wartościowania - np. według Emila Durkheima wartości to narzucane społecznie normy);

- w przedmiocie (definicje obiektywistyczne - np. według Romana Ingardena wartość jest zawsze nadbudowana nad swym nosicielem i wypływa z jego istoty, a Tatarkiewicz podkreśla, że wartość jest przedmiotem czyjegoś doświadczenia);

- bądź poza nimi, w sferze autonomicznej (definicje absolutystyczne, poszukujące 
wartości w jakiejś innej, idealnej sferze rzeczywistości).

Etyk Tadeusz Ślipko określa wartości jako ogólne wzory postępowania, a filozof ks. Józef Tischner stwierdza, że wartości pojawiają się, gdy w polu naszej świadomości staje jakaś osoba i ujawniają się między osobami i tym, co się między nimi wydarza (Pawliszyn 2006, 110). Filozof i socjolog Florian Znaniecki wartości traktuje jako obiekty determinujące określone przeżycia psychiczne i działania jednostek, członków grupy społecznej. Wartości są tym, co może stanowić potencjalny przedmiot ludzkich działań (Błasiak 2009, 40). Z kolei socjologiczna definicja Jana Szczepańskiego ujmuje wartość jako dowolny przedmiot wyimaginowany, w stosunku do którego jednostki lub zbiorowości przyjmują postawę szacunku, przypisują mu ważną rolę w swoim życiu i dążenie do jego osiągnięcia odczuwają jako ważny przymus (Lipińska 2010, 128). Przez pryzmat ludzkich dążeń postrzegane są wartości także w encyklopedii PWN (2020), według której wartość to podstawowa kategoria aksjologii oznaczająca wszystko to, co cenne i godne pożądania, co stanowi cel ludzkich dążeń.

Uważany za klasyka problematyki wartości rozpatrywanych z psychologicznego punktu widzenia, Milton Rokeach w 1973 r. zdefiniował wartość jako trwałe przekonanie, że dany sposób postępowania lub ostateczny cel życia jest jednostkowo i społecznie bardziej atrakcyjny niż inne sposoby zachowania się i inne cele życiowe (Górniak 2015, 102). Podobne podejście zaprezentował w 1951 r. Clyde Kluckhohn, uznając, że wartości są jawnymi lub ukrytymi określeniami „pożądanego”, które wpływają na działania jednostki i sposoby ich realizacji (Górniak 2015, 102-103). W podejściu psychologicznym w ujęciu Shalom H. Schwartza uznaje się, że wartości (Cieciuch 2013, 38):

- są przekonaniami,

- odnoszą się do pożądanych celów,

- wykraczają poza konkretne działania i sytuacje,
- kierują wyborem, służąc jako standardy lub kryteria,

- są uporządkowane względem siebie według ważności.

Podobnie jak w odniesieniu do jednostki, ujmuje się wartości w kontekście organizacji. Znowu podkreślając, że wobec wieloznaczności pojęcia kultury organizacyjnej (której wartości są składnikiem) trudne staje się zdefiniowanie samych wartości (KrajewskaNieckarz 2013, 214-215).

Najlapidarniej wyjaśnia czym są wartości organizacyjne Geert Hofstede - to skłonności do dokonywania określonego wyboru (Lipińska 2010, 127). Czesław Sikorski definiuje wartości organizacyjne jako „przedmioty, stany rzeczy lub sytuacje, które ludzie cenią i starają się osiągnąć poprzez swoje uczestnictwo w organizacji" (Krajewska-Nieckarz 2013, 215). Nieco inaczej pojęcie to interpretuje Marek Bugdol, uznając, że wartości organizacji odzwierciedlają specyfikę, strukturę, układ stosunków społecznych i celowość działania organizacji, są elementem składowym relacji międzyludzkich, kultury organizacyjnej, systemów wartości i systemów etycznych oraz przyczyniają się do powstawania nowych wartości, zarówno niematerialnych, jak i materialnych (Mierzwińska 2013, 343). Z kolei Francuski Instytut Gospodarki Polska w bardzo praktycznej definicji przyjmuje, że wartości organizacji to „zestaw wspólnych cech, które charakteryzują zachowania, postawy oraz determinują działania poszczególnych osób w organizacji, a tym samym często stanowią kryteria podejmowania decyzji i dokonywania wyborów" (FIG Polska 2020).

Mnogość definicji wartości przekłada się na wielość ich kategoryzacji. Ponieważ wartości organizacji mogą mieć charakter nie tylko etyczny, lecz także ekonomiczny, czy też prakseologiczny, najczęściej przyjmuje się podział dychotomiczny na wartości ostateczne i instrumentalne - Rokeach (Cieciuch 2013, 29), podstawowe - egzystencjalne (podmiotowe i abstrakcyjne) i pochodne - instrumentalne (przedmiotowe i konkretne) - Hausner (2019, 46-47), 
podstawowe/ostateczne i operacyjne/instrumentalne - wspomniani Dolan, Garcia i Alan Auerbach (Jaakson 2010, 798). W innym, bardziej szczegółowym i odnoszącym się do jednostki podejściu wyróżnia się wartości absolutne (religijne), duchowe, witalne, utylitarne, hedonistyczne - fenomenolog Max Scheler (Brzozowski 2005, 262), czy witalne, utylitarne, techniczne, moralne, osobowe, poznawcze, kulturowe, społeczne - Maria Gołaszewska (Dudek 2018, 31). Odmienne ujęcie zaproponowali wspomniani już Dolan, Richley i Garcia wraz z Tonym Linghamem (2008), dzieląc wartości na ekonomiczno-pragmatyczne, etyczno-społeczne i emocjonalno-rozwojowe. $Z$ kolei Pablo Cardona i Carlos Rey $(2009,87)$ sklasyfikowali wartości przedsiębiorstw następująco: biznesowe, racjonalne, rozwojowe i związane z wkładem na rzecz innych.

Nieco podobną do ich typologię przyjęto w ramach opracowywania Corporate Values Index 2013. Na potrzeby tego badania wartości zostały podzielone na (ECCO International Communications Network 2013):

- profesjonalne (professional) - określające główną działalność przedsiębiorstwa, jego najważniejsze cechy oraz definiujące jakość produktów,

- konkurencyjności (competitive) - wskazujące na cechy, dzięki którym firma ma zamiar osiągnąć sukces i przewagę konkurencyjną,

- behawioralne (behavioural) - opisujące sposoby działania przedsiębiorstwa i jego pracowników,

- społecznościowe (societal) - charakteryzujące stosunek firmy do otoczenia i środowiska,

- relacyjne (relational) - definiujące sposób komunikacji z otoczeniem,

- moralne (moral) - wartości etyczne i moralne pracowników organizacji oraz zasady moralne, którym hołduje organizacja,

- samorealizacji (fulfilling) - wzbogacające, wskazujące na cechy pracowników przedsiębiorstwa,
- społeczne (social) - wartości, jakie organizacja dzieli ze społeczeństwem.

Uwzględniając stopień ich „zakorzenienia”, Jan Szczepański wyróżnia wartości odczuwane (zinternalizowane tak głęboko, że postrzegane jako element wewnętrznego świata człowieka), uznawane (takie, o których człowiek wie, że powinny być dla niego atrakcyjne i że powinien je cenić) oraz realizowane (mogą nimi być zarówno wartości odczuwane, jak i uznawane) (Lipińska 2010, 129). Zintegrowanie pracowników wokół wartości organizacji oznacza przekonanie ich do stosowania tych wartości w praktyce. Wówczas wartości deklarowane (espoused values, stated values, value-driven) stają się wartościami faktycznie stosowanymi (values in use) i jako takie wywierają najmocniejszy wpływ na funkcjonowanie przedsiębiorstwa w otoczeniu bliższym i dalszym (Krajewska-Nieckarz 2013, 217). Krista Jaakson podkreśla, że deklaracja wartości jest tylko wierzchołkiem góry lodowej wdrażania wartości organizacyjnych - jedynie fragmentem tego, co jest widoczne dla innych. Wartości faktycznie manifestowane w organizacji nie zawsze muszą być uświadomione. Trzeba o tym pamiętać, bo wartości deklarowane nie moga pozostawać w kontrze do tych rzeczywiście podzielanych w organizacji (Jaakson 2010, 796-797).

Wartości organizacyjne są wytworem zarówno wewnętrznych, jak i zewnętrznych czynników. Z jednej strony wartości organizacji są często odbiciem wartości przywódców, którzy kształtują kulturę organizacyjną, z drugiej strony - pracownicy przychodzą do organizacji z wartościami już ukształtowanymi. Zarządzanie poprzez wartości służyć może dopasowaniu obu tych systemów. Harmonizacja wartości osoby i organizacji przekłada się zarówno na wzrost poziomu zaspokojenia potrzeb jednostki, jak i wzrost poziomu wydajności organizacji (Stachowicz-Stanusch 2007, 84-89). Dopasowanie wartości pracowników i organizacji wpływa także pozytywnie na zaangażowanie, motywację, lojalność, satysfakcję i zadowolenie pracowników (dzięki ich podmiotowemu 
traktowaniu), jakość i spójność działań w przedsiębiorstwie, a tym samym na jego pozycję konkurencyjną (Lewandowska 2009, 6-7). Warto przy tym pamiętać, że wartości mogą nie tylko wspierać cele organizacji, lecz też je kształtować. W przeciwieństwie do określonych ilościowo lub jakościowo celów są poziomami doskonałości, do których można cały czas dążyć (Lewandowska 2009, 7). Jak zauważa Lech Górniak (2015, 103), „ «myślenie wartościami» pozwala dookreślić cel, znaleźć odpowiednią drogę i dobrać właściwą strategię działania wszędzie tam, gdzie sytuacje nie są dobrze dookreślone".

\section{Wartości organizacyjne w przedsiębiorstwach}

ECCO International Communications $\mathrm{Ne}$ twork przeprowadził trzy edycje (2006, 2009 i 2013) badania nad wartościami przedsiębiorstw (pierwsza obejmowała tylko Francję, dwie kolejne były międzynarodowe). $\mathrm{Na}$ potrzeby Corporate Value Index 2013 przeanalizowano 4348 firm różnej wielkości reprezentujących 14 sektorów i pochodzących z 13 krajów (w tym Polski) (ECCO International Communications Network 2013). Od pierwszej edycji indeksu w 2006 r. niezmiennie najpopularniejszymi wartościami były innowacyjność (wartość z rodziny profesjonalnych) i jakość (zaliczana do wartości konkurencyjności) (w 2013 r. wskazało je odpowiednio $40 \%$ i $30 \%$ badanych firm, w Polsce - 31\% i 36\%) - tabela 2 .

Analizowane w badaniu wartości firm (22 $993 \mathrm{w} 2013 \mathrm{r}$.) pogrupowano w rodziny wartości. We wszystkich edycjach indeksu wśród kategorii wartości dominowały profesjonalne (33\% ogółu w 2013 r.), konkurencyjności $(21 \%)$, behawioralne (15\%), podobnie było w przypadku Polski (w 2013 r. odpowiednio $39 \%, 21 \%, 11 \%)$. W ostatniej edycji, w stosunku do pierwszej, nastąpił wzrost wartości zaliczanych do rodziny behawioralnych (o 3 p.p.), relacyjnych (o 2 p.p.), samorealizacji i społecznych (o po 1 p.p.), co jest zgodne z oczekiwaniami interesariuszy i zmianami zachodzącymi w otoczeniu firm. W analogicznym okresie w przypadku Polski można było zaobserwować zwiększenie wartości należących do kategorii profesjonalnych (o 4 p.p.), konkurencyjności (o 3 p.p.), relacyjnych (o 2 p.p.) i samorealizacji (o 1 p.p.) - w Polsce zatem firmy nadal przede wszystkim stawiały na tradycyjne wartości biznesowe.

Wykorzystując metodologię ECCO International Communications Network, Tomasz J. Dąbrowski z SGH w Warszawie przeprowadził w 2017 r. badanie 140 spółek publicznych notowanych na rynku regulowanym Giełdy Papierów Wartościowych w Warszawie i należących do indeksów: WIG 20, mWIG4o i sWIG8o. Wartości komunikowało ok. 47\% wybranych do badania firm (Dąbrowski 2018, 37-38). Po zagregowaniu znaczeniowo wartości, Dąbrowski (2018: 44) do wartości, do których badane spółki najczęściej się odnosiły, zaliczył: odpowiedzialność (25 wskazań), innowacyjność, klienta, uczciwość (po 15), profesjonalizm, szacunek (po 12), zaufanie (11). Analizując z kolei udział poszczególnych rodzin wartości w deklarowanych przez firmy wartościach, za najpopularniejsze kategorie Dąbrowski (2018: 43) uznał: wartości profesjonalne (25\% ogółu wartości), behawioralne (20\%), relacyjne (15\%), konkurencyjności $(14 \%)$, moralne (10\%), społecznościowe (9\%), samorealizacji (4\%) i społeczne (3\%). Podobny ranking rodzin wartości utrzymywał się przy popularności mierzonej liczbą spółek, w których zidentyfikowano wartości należące do danej rodziny - jedynie kategorie wartości relacyjnych i konkurencyjności zamieniły się miejscami (Dąbrowski 2018, 41).

\section{Wartości organizacyjne liderów CSR w Polsce - wyniki autorskiego badania}

Bezpośrednim celem przeprowadzonego przez autorkę badania było zidentyfikowanie charakteru oraz częstości występowania wartości organizacyjnych deklarowanych przez liderów CSR w Polsce, a celem pośrednim - ocena komunikowania tych wartości (ponieważ na potrzeby badania analizowano firmowe strony internetowe, $\mathrm{w}$ tym 
Tabela 2. Zestawienie dziesięciu najczęściej występujących wartości w trzech edycjach Corporate Value Index 2013 na tle wyników dla Polski

\begin{tabular}{|c|c|c|c|c|c|c|c|}
\hline $\begin{array}{c}\text { Edycja } 2013 \\
\text { Polska }\end{array}$ & $\%$ & $\begin{array}{c}\text { Edycja } 2013 \\
\text { ogółem }\end{array}$ & $\%$ & $\begin{array}{c}\text { Edycja } 2009 \\
\text { ogółem }\end{array}$ & $\%$ & $\begin{array}{c}\text { Edycja } 2006 \\
\text { ogółem }\end{array}$ & $\%$ \\
\hline jakość & 36 & innowacyjność & 40 & jakość & 40 & jakość & 38 \\
\hline innowacyjność & 31 & jakość & 30 & innowacyjność & 39 & innowacyjność & 38 \\
\hline $\begin{array}{l}\text { zadowolenie } \\
\text { klienta }\end{array}$ & 29 & zadowolenie klienta & 28 & zadowolenie klienta & 26 & zadowolenie klienta & 37 \\
\hline know-how & 21 & uczciwość & 20 & uczciwość & 19 & uczciwość & 19 \\
\hline sukces & 18 & ochrona środowiska & 17 & ochrona środowiska & 18 & duch zespołowy & 18 \\
\hline $\begin{array}{l}\text { odpowiedzialność } \\
\text { społeczna }\end{array}$ & 17 & profesjonalizm & 16 & $\begin{array}{l}\text { odpowiedzialność } \\
\text { społeczna }\end{array}$ & 17 & ochrona środowiska & 18 \\
\hline zaufanie & 16 & odpowiedzialność & 14 & sukces & 16 & know-how & 17 \\
\hline profesjonalizm & 13 & duch zespołowy & 12 & know-how & 16 & sukces & 14 \\
\hline środowisko & 13 & szacunek & 12 & odpowiedzialność & 15 & $\begin{array}{l}\text { odpowiedzialność } \\
\text { społeczna }\end{array}$ & 13 \\
\hline Uczciwość & 13 & ambicja & 11 & duch zespołowy & 13 & szacunek & 12 \\
\hline
\end{tabular}

Źródło: opracowanie własne na podstawie: (ECCO International Communications Network 2013)

zamieszczone tam kodeksy i raporty CSR). Badaniem objęto 72 firmy wchodzące w skład Rankingu Odpowiedzialnych Firm 2019 (13. edycja ROF), chcąc ocenić, jakimi wartościami kierują się firmy uznawane za liderów społecznej odpowiedzialności w Polsce, zważywszy, że koncepcja ta opiera się na etyczności, przejrzystości i wiarygodności, a także budowaniu trwałych relacji z interesariuszami. Badanie przeprowadzono w listopadzie 2019 r. Spośród wytypowanych do badania 72 firm swoje wartości komunikowało $61 \mathrm{i}$ te poddano dalszym analizom (warto podkreślić dużo wyższy odsetek liderów CSR komunikujących swoje wartości w porównaniu do spółek giełdowych $-84 \%$ wobec ok. 47\%). Wobec mnogości klasyfikacji wartości i ze względów porównawczych w badaniu zdecydowano się wykorzystać metodologię ECCO Network.

Analizując strony internetowe liderów CSR w poszukiwaniu deklarowanych przez nich wartości, stwierdzono, że najczęściej firmy komunikowały je w zakładce poświęconej ogólnym informacjom o przedsiębiorstwie („O nas”) - 16 przypadków, albo zakładce przedstawiającej misję, wizję i wartości - 12. W ten sposób firmy, kierując przekaz dotyczący wartości do szerokiego grona interesariuszy, podkreślały wysoką rangę przyjętych w organizacji wartości. Część firm informację o wartościach zamieszczała bądź w raporcie CSR (8 przypadków) czy kodeksie etycznym (7), bądź na stronie internetowej w zakładce „Odpowiedzialność” (7), sugerując tym samym wąskie, funkcjonalne podejście do ZPW. Zdarzały się także sytuacje, kiedy analizowane firmy komunikację dotyczącą wartości kierowały wyłącznie do potencjalnych pracowników (zakładka „kariera” na stronie internetowej) - 5 przypadków.

61 analizowanych firm deklarowało w sumie 272 wartości organizacyjne. Najczęściej badane firmy deklarowały 4 lub 3 wartości rys. 1. Po uporządkowaniu wartości organizacyjnych otrzymano 284 wartości rodzinne, tj. dające się przypisać do jednej z 8 rodzin wartości ECCO Network. Uporządkowanie wartości z jednej strony polegało na agregacji wartości bliskich znaczeniowo w wiodącą wartość rodzinną (np. do wartości rodzinnej „klient” zaliczono takie wartości organizacyjne, jak np.: „satysfakcja klienta”, „orientacja na klienta”, „zadowolenie klienta”, „wspólny sukces z klientami”, „blisko klienta”, "dla klientów staramy się bardziej niż ktokolwiek inny"). Z drugiej strony uporządkowanie wiązało się z odczytaniem znaczenia wartości organizacyjnej, w oparciu o definicję danej wartości, a wobec braku takowej 
- kontekstowo (np. wartość „troska o naszych ludzi” została zaliczona do wartości samorealizacji, natomiast wartość „zobowiązanie wobec ludzi" - do społecznościowych, "czystość" zaś zaliczona była w jednym przypadku do społecznościowych, w innym - do moralnych). Uporządkowanie nie przełożyło się na zmniejszenie liczby analizowanych wartości, ponieważ zdarzało się, że w jednej wartości organizacyjnej ukrytych było kilka wartości rodzinnych (np. wartość organizacyjna „jakość i innowacyjność są naszą pasją" zawiera w sobie 3 wartości rodzinne - w kolejności: profesjonalną, konkurencyjności i behawioralną). Część jednak wartości organizacyjnych była zarazem wartościami rodzinnymi (np. odpowiedzialność, profesjonalizm, jakość, innowacyjność, otwartość, pasja).

Przeprowadzone badanie pozwoliło stwierdzić, że do najczęściej deklarowanych przez liderów CSR w Polsce wartości należała przede wszystkim odpowiedzialność zaliczana do wartości behawioralnych (25 wskazań), dopiero w dalszej kolejności uczciwość - wartość moralna (13), współpraca, szacunek zaliczane do rodziny relacyjnych (po 11) oraz klient - wartość profesjonalna (11), a także otwartość będąca wartością behawioralną (10) - rys. 2 .

Zestawienie najczęściej deklarowanych wartości już sugeruje, że najpopularniejszą wśród badanych firm rodziną wartości były wartości behawioralne (zalicza się do nich takie wartości, jak np. odpowiedzialność, otwartość, zaangażowanie, pasja, prostota, pokora, kreatywność, wolność) - 24\% ogółu wartości. Nieco dalej plasowały się wartości profesjonalne (np. klient, profesjonalizm, doskonałość, niezawodność, praca zespołowa, sprawność, sumienność, rzetelność, szybkość) - 18\%, następnie wartości konkurencyjności (np. przedsiębiorczość, rozwój, wiarygodność, innowacyjność, odwaga, przywództwo, ambicja, efektywność) - 17\% oraz relacyjne (np. współpraca, szacunek, zaufanie, komunikacja, bliskość, tolerancja, uważność) - 16\%. Dalsze pozycje zajmowały wartości moralne (np. uczciwość, przejrzystość, etyka, szczerość) oraz samorealizacji (np. ludzie, humanizm, wrażliwość, radość). Ostatnie pozycje zajmowały wartości społecznościowe (np. odpowiedzialny rozwój, bezpieczeństwo, troska) oraz społeczne (np. sprawiedliwość, solidarność) - rys. 3 .

Jeśli zmierzy się popularność rodzin wartości liczbą spółek, które zadeklarowały wartość należącą do danej kategorii, to przedstawiony ranking nieco się zmienia choć nadal najliczniej reprezentowana jest rodzina wartości behawioralnych (takie wartości przyjęło 48 firm spośród 61 analizowanych), to na drugim miejscu pojawiły się wartości relacyjne (39), a na trzecim konkurencyjności (34) - rys. 4.

Jak wynika z rys. 3, w której zestawiono najpopularniejsze wartości i rodziny wartości według Corporate Value Index 2013, badań Dąbrowskiego i autorki, od 2013 r. widać wyraźną zmianę priorytetów firm. Kluczowa stała się odpowiedzialność, którą firmy potrafią interpretować bardzo szeroko, odnosząc ją do różnych grup interesariuszy. Widać także wzrost popularności wartości uczciwość (co jest pesymistycznym trendem, bo wydaje się, że uczciwość powinna

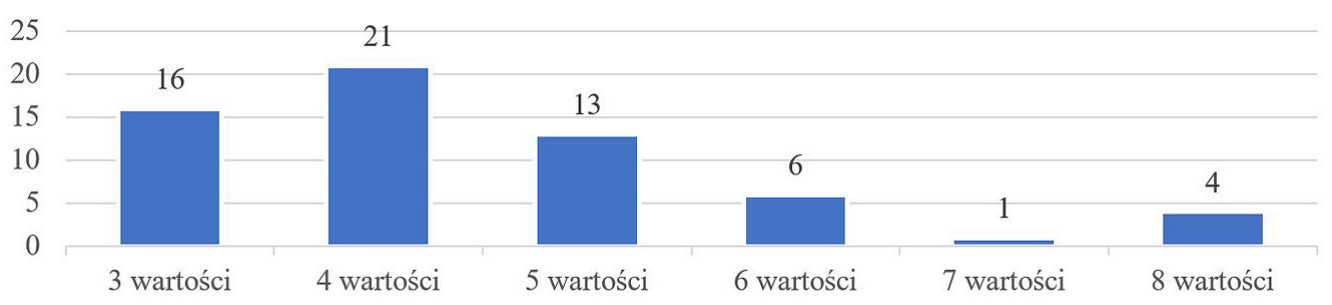

Rys. 1. Liczba wartości organizacyjnych deklarowanych przez badanych liderów CSR w Polsce Źródło: opracowanie własne na podstawie przeprowadzonego badania 


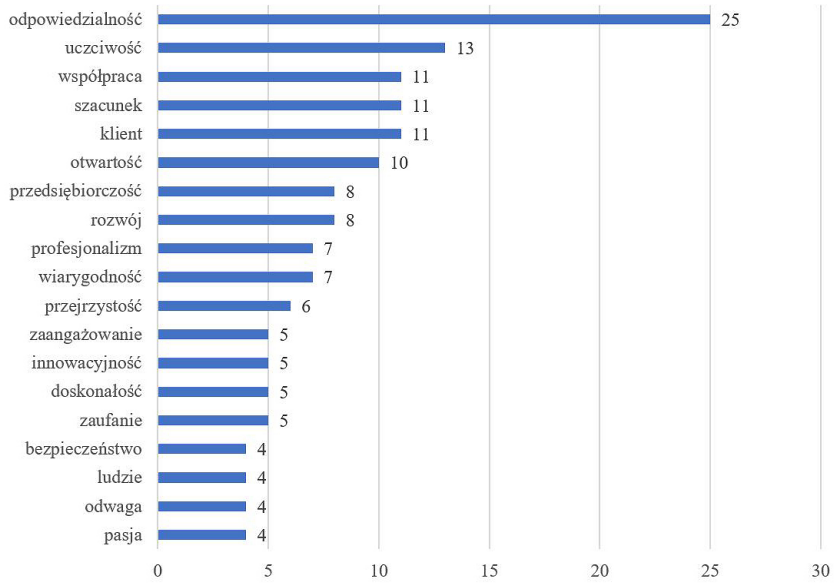

Rys. 2. Najczęściej deklarowane wartości przez liderów CSR w Polsce

Źródło: opracowanie własne na podstawie przeprowadzonego badania

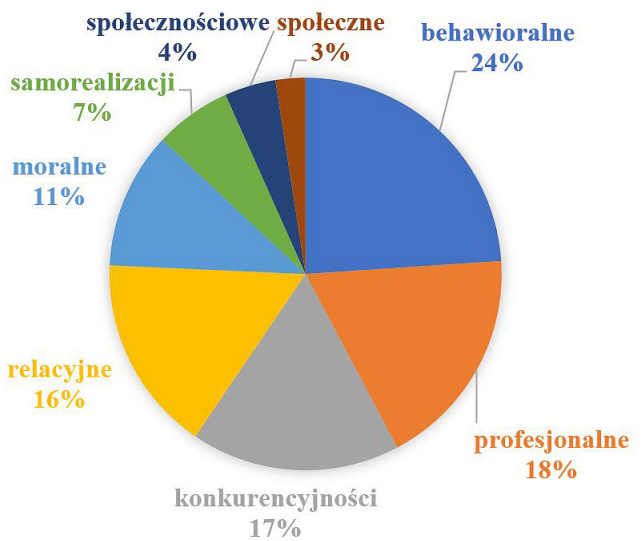

Rys. 3. Popularność rodzin wartości wśród liderów CSR w Polsce (mierzona udziałem wartości należących do danej rodziny w wartościach ogółem)

Źródło: opracowanie własne na podstawie przeprowadzonego badania

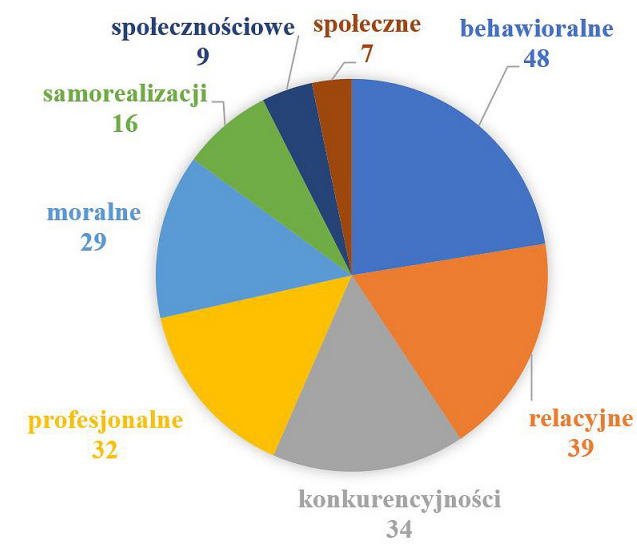

Rys. 4. Popularność rodzin wartości wśród liderów CSR w Polsce (mierzona liczbą firm deklarujących wartości z danej rodziny)

Źródło: opracowanie własne na podstawie przeprowadzonego badania 
Tabela 3. Zestawienie wartości organizacyjnych i rodzin wartości według popularności w przedstawionych badaniach

\begin{tabular}{|c|c|c|c|c|c|}
\hline \multicolumn{2}{|c|}{$\begin{array}{c}\text { Corporate Value Index } 2013 \\
\text { Polska }\end{array}$} & \multicolumn{2}{|c|}{$\begin{array}{c}2017 \mathrm{r} . \\
\text { spółki giełdowe w Polsce }\end{array}$} & \multicolumn{2}{|c|}{$\begin{array}{c}2019 \text { r. } \\
\text { liderzy CSR w Polsce }\end{array}$} \\
\hline wartości & $\begin{array}{c}\text { rodziny wartości } \\
(\% \text { ogółu })\end{array}$ & wartości & $\begin{array}{l}\text { rodziny wartości } \\
\text { (\% ogółu) }\end{array}$ & wartości & $\begin{array}{c}\text { rodziny wartości } \\
(\% \text { ogółu })\end{array}$ \\
\hline jakość & profesjonalne & odpowiedzialność & profesjonalne & odpowiedzialność & behawioralne \\
\hline innowacyjność & konkurencyjności & innowacyjność & behawioralne & uczciwość & profesjonalne \\
\hline $\begin{array}{l}\text { zadowolenie } \\
\text { klienta }\end{array}$ & behawioralne & klient & relacyjne & współpraca & konkurencyjności \\
\hline know-how & społecznościowe & uczciwość & konkurencyjności & szacunek & relacyjne \\
\hline sukces & relacyjne & profesjonalizm & moralne & klient & moralne \\
\hline $\begin{array}{l}\text { odpowiedzialność } \\
\text { społeczna }\end{array}$ & moralne & szacunek & społecznościowe & otwartość & samorealizacji \\
\hline zaufanie & samorealizacji & zaufanie & samorealizacji & przedsiębiorczość & społecznościowe \\
\hline profesjonalizm & społeczne & & społeczne & rozwój & społeczne \\
\hline środowisko & & & & profesjonalizm & \\
\hline uczciwość & & & & wiarygodność & \\
\hline
\end{tabular}

Źródło: opracowanie własne na podstawie: (ECCO International Communications Network 2013; Dąbrowski 2018) oraz przeprowadzonego badania

być standardem postępowania a nie poziomem doskonałości, do którego się cały czas dąży). Straciła na znaczeniu jakość, nadal zaś ważna dla spółek giełdowych innowacyjność nie jest już priorytetem dla liderów CSR, którzy wyraźnie stawiają na wartości nakierowane na budowanie relacji z różnymi interesariuszami (nie tylko klientami, jak spółki giełdowe). Te zmiany można również dostrzec przy analizie rodzin wartości wartości behawioralne $\mathrm{z}$ trzeciego miejsca w 2013 r., poprzez drugie w 2017 r., awansowały do pierwszego w 2019 r. Zaskakujący jest jednak obserwowany w porównywanych badaniach spadek znaczenia wartości społecznościowych (nastawionych na otoczenie i środowisko) oraz brak wartości takiej jak „zrównoważony rozwój” (w kontekście szybko rosnącego zainteresowania firm realizacją Celów Zrównoważonego Rozwoju ONZ - SDGs, Sustainable Development Goals).

\section{Podsumowanie}

Zarządzanie przez wartości jest koncepcją, która odrzuca tradycyjny sposób zarządzania, wychodząc poza ekonomiczny wymiar wartości. Nadal podejście to jest dyskusyjne, bo choć aksjologia jest wąską dyscypliną, wywodzącą się z nauk filozoficznych, to staje się coraz bardziej interdyscyplinarna, wchodząc do innych dziedzin naukowych, jak zarządzanie czy ekonomia. Twórcami koncepcji ZPW są Michael O'Connor i Ken Blanchard, którzy w 1998 r., w książce pod takim samym tytułem, zdefiniowali tę koncepcję jako filozofię i rzeczywisty, praktyczny proces wyjaśniania wartości organizacji, skutecznego ich komunikowania i dostosowywania praktyk biznesowych do nich, aby osiągnąć nowy poziom wyników.

Definicji samych wartości można w literaturze odnaleźć wiele, co jest wyrazem sporu, jaki się w tym zakresie toczy. W podejściu psychologicznym panuje jednak zgoda, że wartości są przekonaniami, odnoszą się do pożądanych celów, wykraczają poza konkretne działania i sytuacje, kierują wyborem, służąc jako standardy lub kryteria oraz są uporządkowane względem siebie według ważności. Trudności występują także w definiowaniu wartości organizacyjnych, co związane jest z wieloznacznością pojęcia kultury organizacyjnej, której wartości są 
składnikiem. Jedna z praktycznych definicji stanowi, że wartości organizacji to zestaw wspólnych cech, które charakteryzują zachowania, postawy oraz determinują działania poszczególnych osób w organizacji, a tym samym często stanowią kryteria podejmowania decyzji i dokonywania wyborów.

Mnogość definicji wartości przekłada się na wielość ich kategoryzacji. Choć większość autorów stosuje dychotomiczny podział wartości na podstawowe i instrumentalne, $\mathrm{w}$ niniejszej pracy szerzej przedstawiono typologię wartości przyjętą w ramach Corporate Values Index, która dzieli wartości na: profesjonalne, konkurencyjności, behawioralne, społecznościowe, relacyjne, moralne, samorealizacji i społeczne. Metodologia tego badania została wykorzystana przez autorkę w badaniach własnych przeprowadzonych wśród liderów CSR w Polsce.

Badanie pozwoliło stwierdzić, że do najczęściej deklarowanych przez liderów CSR w Polsce wartości należały: odpowiedzialność, uczciwość, współpraca, szacunek, klient i otwartość. Do najpopularniejszych zaś rodzin wartości należały wartości behawioralne, następnie profesjonalne i konkurencyjności oraz relacyjne. Zestawiając wyniki autorskiego badania z Corporate Value Index i badaniami Tomasza J. Dąbrowskiego, zauważono wyraźną zmianę priorytetów firm w latach 2013-2019. Kluczowa stała się odpowiedzialność, straciła na znaczeniu jakość, wśród zaś rodzin wartości firmy zaczęły stawiać przede wszystkim na wartości behawioralne.

Przeprowadzone badania dotyczyły wartości deklarowanych, natomiast w badaniach nad wartościami organizacyjnymi wyzwaniem jest rozbieżność między wartościami deklarowanymi a rzeczywistymi. Badanie, na ile firmy wdrażają deklarowane wartości w praktyce, wymagałoby oceny konkretnych polityk, programów i działań podejmowanych przez firmy. Wydaje się jednak, że fakt, iż badane przez autorkę firmy są zaliczane do liderów CSR (a koncepcja ta wymaga przejrzystości i wiarygodności), zwiększa prawdopodobieństwo stosowania głoszonych przez firmy wartości w praktyce. Grono liderów CSR w Polsce jest bowiem z jednej strony niezbyt liczne, z drugiej dość stałe, więc firmy te są wielokrotnie poddawane zewnętrznej weryfikacji przy okazji różnych konkursów i rankingów społecznej odpowiedzialności (chociażby ROF) czy publikacji raportów pozafinansowych.

\section{Bibliografia}

Blanchard, Keith, and Michael O'Connor. 1998. Zarzadzanie poprzez wartości. Warszawa: Wydawnictwo Studio Emka.

Błasiak, Anna. 2009. Aksjologiczne aspekty procesu wychowania. Wybrane zagadnienia. Kraków: Wydawnictwo WAM.

Brzozowski, Piotr. 2005. „Uniwersalna hierarchia wartości - fakt czy fikcja?". Przeglad Psychologiczny 48 (3): 261-276.

Cardona, Pablo, i Carlos Rey. 2009. Zarzadzanie poprzez misje. Kraków: Oficyna a Wolters Kluwer business.

Cieciuch, Jan. 2013. Ksztattowanie się systemu wartości od dzieciństwa do wczesnej dorostości. Warszawa: Wydawnictwo Liberi Libri.

Dąbrowski, Tomasz J. 2018. „Wartości organizacyjne spółek publicznych w Polsce." Organizacja i Kierowanie 3(182): 33-48.

Dolan, Simon L., Bonnie A. Richley, Salvador Garcia, i Tony Lingham. 2008. Zarzadzanie przez wartości. Dostęp 23.09.2008. www.cxo.pl/news/ Zarzadzanie-przez-wartosci,325242.html.

Dudek, Joanna. 2018. „Etyka zawodu w myśli prakseologicznej." Problemy Profesjologii 1: 29-41.

ECCO International Communications Network. 2013. International Index of Corporate Values 2013. Materiaty prasowe.

Encyklopedia PWN. 2020. Wartość. Dostęp 15.05.2020. https://encyklopedia.pwn.pl/haslo/ wartosc;3994143.html.

FIG Polska. 2020. Wartości organizacji - narzędzie ksztattowania oczekiwanych postaw i zachowań. Dostęp 30.01.2020. https://figpolska.pl/wartosci-organizacji-narzedzie-ksztaltowania-oczekiwanych-postaw-i-zachowan/.

Górniak, Lech. 2015. „Zarządzanie przez wartości jako metoda angażowania pracowników." Zeszyty Naukowe Uniwersytetu Ekonomicznego w Krakowie 8 (944): 101-116. 
Hausner, Jerzy. 2019, Społeczna czasoprzestrzeń gospodarowania. W kierunku ekonomii wartości. Warszawa: Wydawnictwo Nieoczywiste.

Herman, Andrzej. 2015. „Aksjologiczne aspekty teorii i praktyki zarządzania wartością." Kwartalnik Nauk o Przedsiębiorstwie 2: 19-37.

Jaakson, Krista. 2010. "Management by values: are some values better than others?". Journal of Management Development 29 (9): 795-806.

Jastrzębska, Ewa. 2014. „Kodeks etyczny jako element zarządzania przez wartości." Prace Naukowe Uniwersytetu Ekonomicznego we Wroctawiu 338: 78-87.

Kaczmarczyk, Paweł. 2018. „Rola wartości w przedsiębiorstwie - wpływ na zarządzanie przedsiębiorstwem." Modern Management Review 25 (1): 61-81.

Koza-Granosz, Maja. 2011. „Aksjologia jako dyscyplina scalająca filozofię i nauki o kulturze." Kultura i Historia 19. Dostęp 23.03.2020. www. kulturaihistoria.umcs.lublin.pl/archives/2101.

Krajewska-Nieckarz, Małgorzata. 2013. „Rola wartości w zarządzaniu organizacją." Zarzadzanie i Finanse 11 (1) cz. 3: 213-228.

Lewandowska, Adrianna. 2009. „Identyfikacja kluczowych wartości jako istotny element konkurowania firm rodzinnych". W Zarzadzanie w XXI wieku. Koncepcje, trendy, problemy, red. Bohdan Godziszewski, Bożena Kołosowska i Jolanta Szołno-Koguc, 1-10. Toruń: Wydawnictwo WSB.

Lifeassociatesinc.com. 2020. Managing by Values. Accessed 30.01.2020. www.lifeassociatesinc.com/ mbv.php.

Lipińska, Justyna. 2010. „Zarządzanie przez wartości." W Komputerowo zintegrowane zarzadzanie, red. Ryszard Knosal, 122-131. Opole: Oficyna wydawnicza Polskiego Towarzystwa Zarządzania Produkcją.

Mierzwińska, Liliana. 2013. „Zarządzanie przez wartości jako koncepcja łącząca paradygmat etyczny i ekonomiczny we współczesnej organizacji." Nierówności społeczne a wzrost gospodarczy 34: 339-347.

Norma PN-ISO26000. 2012. Wytyczne dotyczace społecznej odpowiedzialności. Warszawa: PKN.

Pawliszyn, Mirosław. 2006. „O definicji wartości, czyli co Władysław Tatarkiewicz ma do zakomunikowania filozofom." Studia Redemptorystowskie 4: 109-116.

Petriglieri, Gianpiero. 2020. Prawdziwy problem dzisiejszych przywódców. Dostęp 15.05.2020. www. hbrp.pl/b/prawdziwy-problem-dzisiejszych-przywodcow/103yAw12g.

Stachowicz-Stanusch, Agata. 2007. Potęga wartości. Jak zbudować nieśmiertelna firmę. Gliwice: Wydawnictwo Helion.

Thaler, Richard H. 2018. Zachowania niepoprawne. Tworzenie ekonomii behawioralnej. Poznań: Media Rodzina.

Tokarczuk, Olga. 2019. Przemowa noblowska. Czuty narrator. Dostęp 7.12.2019. www. nobelprize.org/prizes/literature/2018/ tokarczuk/104870-lecture-polish/.

Waterman Jr., Robert H., Thomas J. Peters and Julien R. Phillips. 1980. "Structure Is Not Organization." Business Horizons 23 (3) (June): 14-26. https://doi. org/10.1016/0007-6813(80)90027-0.

Wiśniewski, Ryszard. 1989. „Podstawy aksjologii Władysława Tatarkiewicza." W Człowiek $i$ wartości moralne. Studia z dziejów niezależnej myśli etycznej, red. Zdzisław J. Czarnecki, Stanisław Soldenhoff, 289-312. Lublin: Wydawnictwo Lubelskie. 